\title{
An Academic Library Publications Committee: Twelve Years Later
}

\begin{abstract}
A standing library committee, formed twelve years ago for the purpose of publishing manuscripts and bibliographies prepared by the members of the library staff and faculty, is now a successful commercial venture. Operational and policy changes are discussed, and present and forthcoming publications are cited.
\end{abstract}

I N RECENT YEARS publishing has become an important part of an academic librarian's professional duties. It has not always been easy to find commercial outlets for librarians' products because of a limited market and low profit. Most of their books are addressed to some aspect of their profession or to a narrow scholarly discipline.

With what may today appear to be uncanny foresight, the Ohio State University Libraries established in 1964, as one of its permanent standing committees, the Libraries' Publication Committee. Its original intent was to provide the unique resources of the university community, especially that of the professional librarians, to all interested parties. At its inception, its goals were threefold:

1. To assist and advise in matters pertaining to Ohio State University Libraries publications;

2. To promote wider distribution of information;

3. To establish the criteria of selection for the Ohio State University

Until her death in November 1976, Jane L. Nelson was head, Journalism Library, Ohio State University Libraries, Columbus. The manuscript for this article was accepted for publication on September 29, 1976. collection (a special collection of publications about the university, or by its faculty members ). ${ }^{1}$

In essence it was a classic standing committee assigned to produce the few house organs standard to library operations. However, with some initial successes, its responsibilities began to expand. The first committee consisted of five members (one ex-officio), appointed by the director of libraries. The remaining four members were chosen to serve two-year terms. The ex-officio member was the assistant director of administrative services. This assistant director was the library budget officer and so was a logical person to serve on the committee. (When the last incumbent of this position resigned, the position itself was abolished, and thus there is no longer this member on the committee.)

Originally the committee was funded by a small sum allocated by the libraries, with the understanding that it would strive to become self-supporting within a reasonable period of time. It was further charged with the responsibility of fostering and encouraging further research and publication by the libraries' faculty and staff.

In one year's time, the committee did, 
indeed, become virtually self-supporting, and twelve years later it is operating at a slight profit. This so-called profit is generally used to launch new titles as there is some initial expenditure in getting a book to the market.

In the early years, the committee handled exhibition catalogs and guides and individual works for which there was a demonstrated need. In this category was Deardorf's Indexes to the United Nations Security Council Papers Index 1946-1964 (1969) and Natural Resources Bibliography (1970). Publications were limited to paperbound editions, which were produced from camera-ready copy. Among the first ventures were the Catalogue of the Talford P. Linn Collection of Cervantes Materials in the Ohio State University Libraries (1964), Katz' Twenty-One Letters from Hart Crane to George Bryan (1968), and Physiological Factors Relating to Terrestrial Altitudes: a Bibliography (1968). Copies of these publications are no longer available for sale.

In 1970 the committee issued its first periodical, Under the Sign of Pisces: Anaïs Nin and Her Circle, a quarterly journal which is still being published. In subsequent years several other journals were launched. However, they did not prove successful in terms of subscriptions, and they were gradually abandoned. One prime example was The New Daguerrian Journal, a quarterly concerned with aspects of early photography. The required paper work and clerical assistance needed for their circulation and related activities made them a deficit operation.

A 1971 list of projects, both proposed and in progress, indicated a preponderance of bibliographies-for example: Healer's Programmed Instruction in Textiles; Manuscripts from the Hilandar Monastery, Mount Athos, in The $O S U$ Libraries; and A Guide to Reference and Bibliography for Theatre Re- search. Today the list contains scholarly titles primarily.

At the end of the first five years of operation, committee activities were described in an article in this journal. ${ }^{2}$ It seems appropriate to review developments at the twelve-year mark as many changes have been instituted in the past seven years.

\section{Committee Procedures}

As the publications committee proved its worth as a publisher and distributor, manuscripts began to be submitted from outside the Ohio State University community. The fact that it will publish titles with limited appeal and in small quantity offers an author an opportunity to have a title published which will have a small audience and which a commercial publisher might not consider.

When a manuscript is received, one member is assigned to it, although all members must decide whether or not to publish it. Most of the time, an outside opinion is solicited as to the value of the manuscript in its special subject field. The committee has been careful in its selection of subjects it will publish, taking into account such factors as scope of audience, cost of production, and price at which it can be sold.

Once the committee reaches a unanimous decision to publish a manuscript, members may request some revisions if they seem necessary. When the manuscript is finally acceptable, a contract is negotiated with the author, stipulating the terms under which the manuscript will be handled. Depending on the type and/or length of the material, a decision is made as to whether camera-ready copy will be required or the services of a commercial printer will be used. Liaison continues with the author until the published work is on the market, and often for a period of time following publication.

During the past few years as the proj- 
ects have become more ambitious, this has often become a frustrating and time-consuming task. In one instance, negotiations were carried on for almost two years before the receipt of the completed manuscript. Sometimes seemingly irrational demands are made concerning type of advertising to be employed, method of publication, number of free review copies issued, etc. One of the titles released in 1975 generated a prepublication investment of almost $\$ 10$,000. At present, it appears that Scholar's Market, a comprehensive directory of 848 periodicals that publish literary scholarship, will recover this investment through its sales.

It is always difficult to predict just which titles will be successful and which will be failures in terms of sale and revenue. Sometimes the publication never brings in a return of the initial investment, in which case the title is reviewed by the committee after a reasonable period of time has elapsed. Generally, the decision is made to drop it from the list when all copies are sold.

The advertising of a new or existing publication is very important from a sales point of view. It has become the practice to develop at least one separate mailing piece for each forthcoming title to be sent to a selected audience. In addition, review copies are sent to appropriate journals. Because of a viable financial situation, it has become possible for the committee to purchase prepared mailing lists geared to specific audiences rather than depending on one supplied by the author as was past practice. Response to these mailings has generally been successful. On some occasions, advertisements of several titles have been placed in pertinent journals.

In 1974 the committee published its first catalog, containing a total of twenty-three titles, including three periodicals, and mailed it to academic and large public libraries. It has since been distributed to many other libraries. (A decision has been made to reissue this catalog in 1978, deleting out-of-print titles and including newly published items.) In 1974 a display was mounted at the annual meeting of the Ohio Library Association, and three titles were submitted to the Combined Book Exhibit for the annual conference of the American Library Association.

Student help has been hired to handle the clerical aspects of the operation, and this aid has removed much of the burden from the already overextended professional members. Many more hours than the eight per week that library faculty members are allocated for research, committee work, etc., are devoted to this operation. ${ }^{3}$ But all members, past and present, agree that it has been a rewarding and informative experience. Each has been forced to learn various aspects of the printing industry, advertising, contractual agreements, the publishing industry, and, most important, the many complications involved in getting works published.

\section{Recent Publications}

One of the earliest and most successful books has been a reprint of a volume entitled The American Frugal Housewife, 12th edition, 1833. This volume has been available from the committee, as well as from several commercial publishers in other editions, in both hard and paperback. It continues to sell at a steady rate, with an increase at the Christmas season.

A more recent undertaking was the publication of ARLO, Art Research Libraries in Ohio, a Union list of Periodicals (1975). This has a limited market, so only a small number of copies were originally printed.

The all-time best seller has to be the Ohio College Library Center's On-line Cataloging. At this writing, over 2,000 copies have been sold, necessitating three printings to date.

Perhaps the most ambitious publica- 
tion so far was Scholar's Market, mentioned earlier.

New and forthcoming volumes from the committee include Beckett's Happy Days, A Manuscript Study; View from The Hague: Letters of William Harrison; and Joe Hewitt's OCLC: Impact and Use. (The committee anticipates that it will have another best seller with the Hewitt volume.) A directory of Ohio associations is in progress.

Including past items, for which copies are still available, the current active list, and these new volumes, there are a total of twenty-five titles from the committee. In view of the fact that membership on the committee rotates constantly, this is an enviable achievement.

\section{Conclusion}

From a fledgling group organized in 1964 for the publication of resources compiled by the professional librarians and other persons in the Ohio State University community, this committee has, in twelve years, achieved quasiprofessional status. Manuscripts are being submitted from many sources outside of the university. The published works of the group are listed in Pub- lishers' Trade List Annual. A sound financial footing has been achieved, and this helps underwrite new publications.

During the 1975/76 academic year, a review was made of all standing library committees. The recommendation was made and adopted that a fifth member be added and that the term of service be extended to three years with overlapping terms.

To the best of this writer's knowledge, this is the only academic publishing venture of its kind. It is unique in its composition and its activity. Its success has been due to astute persons who devote many hours of extracurricular time in its behalf. Its future looks promising.

\section{REFERENCES}

1. Jo-Ann Davis, Roberta Boone, and Irene Braden Hoadley, "Of Making Many Books: A Library Publication Program," College d Research Libraries 32:31-35 (Jan. 1971).

2. Ibid.

3. For a description of the Ohio State University Libraries policy on "nonassigned" time which can be devoted to research, see Susan L. Miller, Kaye Gapen, Irene B. Hoadley, and Rosario Poli, "To Be or Not To Be: An Academic Library Research Committee," Journal of Academic Librarianship 2:20-23 (March 1976). 